\title{
Resistance of extremely halophilic archaea to zinc and zinc oxide nanoparticles
}

\author{
Bhakti B. Salgaonkar · Deepthi Das • \\ Judith Maria Bragança
}

Received: 7 January 2015/Accepted: 23 February 2015/Published online: 10 March 2015

(C) The Author(s) 2015. This article is published with open access at Springerlink.com

\begin{abstract}
Industrialization as well as other anthropogenic activities have resulted in addition of high loads of metal and/or metal nanoparticles to the environment. In this study, the effect of one of the widely used heavy metal, zinc ( $\mathrm{Zn}$ ) and zinc oxide nanoparticles ( $\mathrm{ZnO} \mathrm{NPs}$ ) on extremely halophilic archaea was evaluated. One representative member from four genera namely Halococcus, Haloferax, Halorubrum and Haloarcula of the family Halobacteriaceae was taken as the model organism. All the haloarchaeal genera investigated were resistant to both $\mathrm{ZnCl}_{2}$ and $\mathrm{ZnO}$ NPs at varying concentrations. Halococcus strain BK6 and Haloferax strain BBK2 showed the highest resistance in complex/minimal medium of up to $2.0 / 1.0 \mathrm{mM} \mathrm{ZnCl}_{2}$ and 2.0/1.0-0.5 mM ZnO NP. Accumulation of $\mathrm{ZnCl}_{2} / \mathrm{ZnO} \mathrm{NPs}$ was seen as Haloferax strain BBK2 (287.2/549.6 mg g $\left.{ }^{-1}\right)$ $>$ Halococcus strain BK6 $\left(165.9 / 388.5 \mathrm{mg} \mathrm{g}^{-1}\right)>$ Haloarcula strain BS2 $\left(93.2 / 28.5 \mathrm{mg} \mathrm{g}^{-1}\right)>$ Halorubrum strain BS17 (29.9/16.2 $\left.\mathrm{mg} \mathrm{g}^{-1}\right)$. Scanning electron microscopy and energy dispersive X-ray spectroscopy (SEM-EDX) analysis revealed that bulk $\mathrm{ZnCl}_{2}$ was sorbed at a higher concentration $(21.77 \%)$ on the cell surface of Haloferax strain BBK2 as compared to the $\mathrm{ZnO}$ NPs $(14.89 \%)$.
\end{abstract}

Keywords Halophilic Archaea $\cdot$ Halococcus strain BK6 - Haloferax strain BBK2 - Halorubrum strain $\mathrm{BS} 17 \cdot$ Haloarcula strain $\mathrm{BS} 2 \cdot \mathrm{ZnCl}_{2} \cdot \mathrm{ZnO}$ nanoparticles . Metal tolerance $\cdot$ Growth kinetics

B. B. Salgaonkar · D. Das · J. M. Bragança ( $\square)$ Department of Biological Sciences, Birla Institute of Technology and Science Pilani, K K Birla, Goa Campus, NH 17B, Zuarinagar 403 726, Goa, India

e-mail: judith@goa.bits-pilani.ac.in; jbraganca@yahoo.com

\section{Introduction}

Rapid industrialization and other anthropogenic activities have resulted in drastic environmental pollution. Natural processes like surface runoffs, weathering and/or erosion and anthropogenic activities like mining, industrial effluents, agricultural runoffs and sewage have led to the accumulation of toxic metals and their derivatives like nanoparticles in the environment (Paula et al. 2013; Zhao et al. 2012). Zinc and zinc oxide nanoparticles (ZnO NPs) are of high concern because of their increasing demand in electroplating, galvanization, cosmetics, sunscreens, paints, food industry, anticancer drugs, antimicrobials, ceramics, and semiconductors (Monteiro et al. 2011; Li et al. 2011).

$\mathrm{ZnO}$ NPs have been extensively studied for their antifungal (Candida albicans), antibacterial (Escherichia coli) and antiviral (bacteriophages MS2) effect (Lipovsky et al. 2011; You et al. 2011). There are numerous reports on resistance and/or tolerance of metals by bacterial strains either individually or in consortium (non halophilic) (Gadd 2009). Various mechanisms of $\mathrm{Zn}$ resistance such as physical bioadsorption/sorption, ion exchange, bioprecipitation and intracellular accumulation in microorganisms such as bacteria (Gram-positive and Gram-negative), cyanobacteria (Microcystis aeruginosa) archaea (Halobacterium saccharovorum) and eukarya (diatoms) have been revealed (Gadd 2009; Green-Ruiz et al. 2008; Zeng and Wang 2009; Guine et al. 2006; Mangold et al. 2013; Williams et al. 2013; Gelabert et al. 2006).

$\mathrm{Li}$ et al. (2011) studied the antibacterial activity of $\mathrm{ZnO}$ NPs on bacterial cells and found that Gram-negative bacteria (Pseudomonas putida and E. coli) are more resistant than Gram-positive bacteria (Bacillus subtilis). On the other hand, Sinha et al. (2011) investigated the toxic effect of silver and zinc oxide nanoparticle on mesophilic and

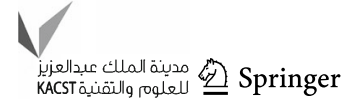


halophilic bacterial cells and concluded that Gram-positive halophiles were able to withstand the toxicity better than their Gram-negative counterparts. Choudhury and Srivastava (2001) compared the data of microorganisms resisting/combating high $\mathrm{Zn}$ by extracellular accumulation or intracellular sequestration by metallothioneins (MT) and efflux by Zn-effluxing ATPases (P-type ATPases) such as ZiaA in Synechocystis and ZntA in E. coli.

Extremely halophilic archaea (order Halobacteriales, family Halobacteriaceae, phylum Euryarchaeota, domain Archaea) inhabit hypersaline regions. (Ma et al. 2010; Mani et al. 2012). They are also reported to have survived approximately 250 millions of years by getting entrapped in salt crystals (Legat et al. 2013; Schubert et al. 2010; Bragança and Furtado 2009). They are polyextremophilic surviving extreme conditions such as high salinity, high temperatures, neutral to alkaline $\mathrm{pH}$, low water activity $\left(a_{\mathrm{w}}\right)$, and extreme gamma radiations (Kottemann et al. 2005). Studies on $\mathrm{Zn}$ resistance in halophilic archaea are scarce. Kaur et al. (2006) proved that P1 ATPases (ZntA and $\mathrm{YvgX}$ ) are responsible for active efflux of the $\mathrm{Zn}$ (II) along with other metals like $\mathrm{Co}(\mathrm{II}), \mathrm{Ni}$ (II) and $\mathrm{Cu}$ (II) in Halobacterium salinarum NRC-1. This study aimed at evaluating the resistance of extremely halophilic archaea to $\mathrm{Zn}$ and $\mathrm{ZnO}$ NPs.

\section{Materials and methods}

Zinc and zinc oxide NPs solutions

Zinc chloride $\left(\mathrm{ZnCl}_{2}\right)$ was obtained from $\mathrm{Sd}$ fine chem. Ltd, Mumbai and Zinc oxide nanoparticles (ZnO NPs) with average particle size $<100 \mathrm{~nm}$ were obtained from SigmaAldrich, USA. Stock solution of ZnO NPs (40.695 $\mathrm{gL}^{-1}$ ) was prepared in deionised water, sonicated at pulse rate of $3-5 \mathrm{~Hz}$ for $15 \mathrm{~min}$ (Microson ${ }^{\mathrm{TM}}$ Sonicator) and autoclaved. Stock solutions of $0.5 \mathrm{M} \mathrm{ZnCl}_{2}\left(68.145 \mathrm{gL}^{-1}\right)$ were prepared in sterile deionized water.

Extremely halophilic archaeal strains and growth medium

Haloarchaeal strains belonging to four different genera used in this study were isolated from salterns of Goa (Mani et al. 2012) and deposited in Microbial Culture Collection (MCC), National Centre for Cell Science, Pune, India. They are Haloferax volcanii strain BBK2 (GenBank/EMBL/DDBJ accession number AB588756; MCC2589), Halococcus salifodinae strain BK6 (GenBank/EMBL/DDBJ accession number AB588757; MCC2602), Haloarcula japonica strain BS2 (GenBank/
EMBL/DDBJ accession number HQ455798; MCC2588), and Halorubrum spp. strain BS17 (GenBank/EMBL/ DDBJ accession number AB971753; MCC2603). Depending upon the strain, two types of complex media were used for optimum growth of the cultures. BBK2 and BK6 were grown in $\mathrm{NaCl}-$ Tryptone Yeast Extract (NTYE) medium, while BS2 and BS17 were grown in $\mathrm{NaCl}-$ Tryptone (NT) medium, both containing $25 \%$ (w/ v) $\mathrm{NaCl}$. The metal studies were carried out in minimal media (referred as NGSM media) with $0.2 \%$ glucose (w/v) as carbon source supplemented with $0.1 \%$ yeast extract (NGSM) (Salgaonkar et al. 2012).

Minimum inhibitory concentration (MIC) studies

MIC of the heavy metal and metal nanoparticles was determined by growing the cultures in complex (NTYE/NT) and minimal media (NGSM) incorporated with $\mathrm{ZnCl}_{2}$ and $\mathrm{ZnO}$ NPs. The MIC was noted by gradually increasing the concentration of metal and metal NPs in the media until the culture ceased to grow. The concentrations of $\mathrm{ZnCl}_{2}$ and $\mathrm{ZnO}$ NPs employed for MIC studies were 0.1, 0.5, 1.0, 2.0 and $4.0 \mathrm{mM}$. The growth was recorded after 5-15 days of incubation.

Growth kinetics in presence of $\mathrm{Zn}$ and $\mathrm{ZnO}$ NPs

The growth kinetics were studied by culturing the selected strains in NGSM with $\mathrm{Zn}$ and $\mathrm{ZnO}$ NPs, concentrations nondetrimental to their growth. They were BK6 $(0.5 \mathrm{mM})$, BBK2 $(0.5 \mathrm{mM})$, BS2 $(0.1 \mathrm{mM})$ and BS17 $(0.1 \mathrm{mM})$. Respective controls were maintained without the $\mathrm{Zn}$ and $\mathrm{ZnO}$ NPs for all experiments. All the flasks were incubated at $37^{\circ} \mathrm{C}$ and $110 \mathrm{rpm}$. The culture growth was monitored after every 24-h interval at $600 \mathrm{~nm}$ by UV-Vis spectrophotometer (UV-2450 Shimadzu, Japan). The growth rate $(\mu)$ and lag phase time $(\lambda)$ were calculated from plot of optical density $\left(\mathrm{OD}_{600} \mathrm{~nm}\right)$ against time using the curvefitting DMFit programme (http://www.ifr.ac.uk/safety/ DMfit) (Baranyi and Roberts 1994).

Pigments analysis of haloarchaeal strains grown in presence of $\mathrm{Zn}$ and $\mathrm{ZnO}$ NPs

Pigments were extracted from stationary phase culture (8-10 days old). The cells were harvested by centrifugation at $8000 \mathrm{rpm}$ for $10 \mathrm{~min}$. To one set of the cell pellet, acetone was added and to the second set chloroform: methanol in the ratio of $(2: 1 \mathrm{v} / \mathrm{v})$ was added. The mixture was vortexed for 5 min until entire pigment (orange-red) was extracted in the solvent. The solvent fraction containing the pigment was separated from the cell debris (colorless or white) by centrifugation at $8000 \mathrm{rpm}$ for $10 \mathrm{~min}$. The 
supernatant was then scanned between 190-800 nm using UV-visible spectrophotometer (Shimadzu UV-2450, Japan).

$\mathrm{Zn}$ accumulation study

\section{Atomic absorption spectroscopy (AAS)}

$10 \mathrm{ml}$ of respective haloarchaeal culture, grown in the presence of $\mathrm{ZnCl}_{2}$ and $\mathrm{ZnO} \mathrm{NPs}(0.1$ and/0.5 mM), was centrifuged at $10,000 \mathrm{rpm}$ for $15 \mathrm{~min}$. The cell pellets were hydrolysed with concentrated nitric acid: sulphuric acid in the ratio of $3: 1(\mathrm{v} / \mathrm{v})$. The mixture was further completely digested in a sand bath at $100{ }^{\circ} \mathrm{C}$ for $3 \mathrm{~h}$ till clear solution was obtained (Das et al. 2014). The solutions were analyzed for $\mathrm{Zn}$ content by GBC atomic absorbtion spectrophotomer (AAS) after appropriate dilution. Standard curve was obtained using a stock of $10 \mathrm{mg} / \mathrm{Zn}^{2+}$ solution. The cell dry weight (CDW) of the haloarchaeal cultures were determined by centrifuging the culture broth at 10,000 rpm for $15 \mathrm{~min}$ and drying overnight at $80^{\circ} \mathrm{C}$.

\section{SEM-EDX analysis}

Late $\log$ phase cells of all four haloarchaeal isolates Haloferax strain BBK2, Halococcus strain BK6, Haloarcula strain BS2 and Halorubrum strain BS17 grown in the presence of $\mathrm{Zn} / \mathrm{ZnO}$ NPs were smeared onto glass slides/coverslips, air dried and desalted with $2 \%$ acetic acid. The cells were fixed for $10 \mathrm{~h}$ with $2 \%$ glutaraldehyde. Samples were dehydrated by exposing to a series of increasing acetone concentrations $(10,30,50,70,90 \%)$, each for $10 \mathrm{~min}$ and finally with $100 \%$ acetone for $30 \mathrm{~min}$. The samples were mounted onto stubs followed by gold coating for SEM-EDX analysis (JEOL-5800 LV SEM). Cobalt stub was used as the standard for EDX analysis.

\section{X-ray diffraction studies (XRD)}

$100 \mathrm{ml}$ of cells of Haloferax strain BBK2 grown in the presence of $0.5 \mathrm{mM} \mathrm{ZnCl}_{2} / 0.5 \mathrm{mM} \mathrm{ZnO} \mathrm{NPs} \mathrm{was}$ harvested by centrifuging at $8,000 \mathrm{rpm}$ for $20 \mathrm{~min}$. The supernatant was discarded and the cell pellet obtained was dialysed against distilled water for $20 \mathrm{~h}$ with regular changes of water after every 3-4 h. The dialysed samples were dried at $80{ }^{\circ} \mathrm{C}$ in a hot air oven for $24 \mathrm{~h}$. With the help of mortar and pestle, the dried cells were pulverized and the X-ray diffraction of the powderized samples was carried at $5^{\circ}-75^{\circ}$ with scanning speed of $2^{\circ} \min ^{-1}$ using the Rigaku Mini-Flex II powder X-ray diffractometer. Cells of Haloferax strain BBK2 grown in absence of metal prepared in the same way were used as control.

\section{Results and discussion}

MIC of $\mathrm{Zn}$ and $\mathrm{ZnO}$ NPs

The minimal inhibitory concentration (MIC) of $\mathrm{Zn}$ and $\mathrm{ZnO}$ NPs on extremely halophilic archaea was assessed as the minimum $\mathrm{Zn}$ concentration that inhibits the growth. The MIC results in NTYE/NT and NGSM are represented in Table 1. The $\mathrm{ZnCl}_{2}$ resistance in complex/minimal media was seen as Halococcus strain BK6 (2.0/ $1.0 \mathrm{mM})>$ Haloferax strain BBK2 $(2.0 / 1.0 \mathrm{mM})>\mathrm{Ha}$ lorubrum strain BS17 $(0.5 / 0.5 \mathrm{mM})=$ Haloarcula strain BS2 $(0.5 / 0.1 \mathrm{mM})$ whereas for $\mathrm{ZnO}$ NPs resistance was BK6 (2.0/1.0 mM) > BBK2 (2.0/0.5 mM) > BS17 (0.5/ $0.5 \mathrm{mM})>\operatorname{BS} 2(0.1 / 0.1 \mathrm{mM})$.

Zinc $(\mathrm{Zn})$ is essential for proper functioning of large number of metalloproteins ( $\mathrm{Zn}$-binding proteins) and is required by organisms of all three domains of life (archaea, bacteria and eukaryote) thereby making it one of the key metal of life (Andreini et al. 2006). However, metals in excess are detrimental and cause cellular damage (Bini 2010). $\mathrm{Zn}$ is toxic to cells due to the formation of reactive oxygen species (ROS) there by inhibiting some of the vital enzymes like endonucleases, DNA glucosylases, etc. Acosta et al. (2011) and Zhao et al. (2013) investigated that increase in ionic strength (salinity) increases the concentration of metal $(\mathrm{Pb}, \mathrm{Cu}, \mathrm{Cd}, \mathrm{Zn}$ and $\mathrm{Mn})$ released. High concentrations of $\mathrm{MgCl}_{2}$ and $\mathrm{NaCl}$ led to an increased release of $\mathrm{Zn}$ from the sediments there by increasing its mobility and bioavailability.

Presence of high concentrations of $\mathrm{NaCl}$ increases the toxicity of $\mathrm{Zn}$ due to the formation of $\mathrm{ZnCl}^{-}$species which is more toxic than the cationic $\mathrm{Zn}^{2+}$ (Nieto et al. 1987). Among all haloarchaeal strains screened, the genera Halococcus and Haloferax showed the best resistance and tolerated highest amount of both $\mathrm{Zn}$ and $\mathrm{ZnO}$ NPs in complex NTYE medium and the minimal medium NGSM. Nieto et al. (1987) in his study of haloarchaeal susceptibility to different heavy metals found that the MIC of $\mathrm{Zn}$ was $0.05-0.5 \mathrm{mM}$. Williams et al. (2013) reported that haloarchaeal strains Halobacterium saccharovorum can tolerate only up to $0.01 \mathrm{mM}$ of $\mathrm{Zn}$. The MIC of $\mathrm{Zn}$ of Haloferax strain BBK2 in NTYE and NGSM media (2.0/ $1.0 \mathrm{mM}$ ) was much higher as compared to reports by Popescu and Dumitru (2009) which was $0.5-1.0 \mathrm{mM}$ of Zn. Gunalan et al. (2012) and Premanathan et al. (2011) reported MIC values of $\mathrm{ZnO}$ NPs for Gram-positive organisms like Staphylococcus aureus is in the range of 0.8-1.5 mM where as that of Gram-negative bacteria like E. coli and Pseudomonas aeruginosa to be $6.1 \mathrm{mM}$.

In metal microbe interactions, the cell wall is the first part of microbe which will contact and interact with the metal. Studies on metal resistance in halophilic bacteria 
Table 1 Minimal inhibitory concentration (MIC) of $\mathrm{ZnCl}_{2}$ (heavy metal) and $\mathrm{ZnO}$ NPs (metal nanoparticles) on four extremely halophilic archaeal genera Halococcus, Haloferax, Halorubrum and Haloarcula grown in complex (NTYE/NT) and minimal (NGSM) media

\begin{tabular}{|c|c|c|c|c|c|c|c|c|}
\hline \multirow[b]{3}{*}{ Growth media } & \multicolumn{8}{|c|}{ Extremely halophilic archaeal cultures } \\
\hline & \multicolumn{2}{|c|}{ Halococcus strain BK6 } & \multicolumn{2}{|c|}{ Haloferax strain BBK2 } & \multicolumn{2}{|c|}{ Halorubrum strain BS17 } & \multicolumn{2}{|c|}{ Haloarcula strain BS } \\
\hline & NTYE & NGSM & NTYE & NGSM & NT & NGSM & NT & NGSM \\
\hline \multicolumn{9}{|c|}{ Heavy metal $\left(\mathrm{ZnCl}_{2}\right) \mathrm{mM}$} \\
\hline Control & +++ & +++ & +++ & +++ & +++ & +++ & +++ & +++ \\
\hline 0.1 & +++ & +++ & +++ & +++ & ++ & ++ & ++ & ++ \\
\hline 0.5 & +++ & ++ & ++ & ++ & + & + & + & \pm \\
\hline 1 & ++ & ++ & + & + & - & - & - & - \\
\hline 2 & + & - & + & - & - & - & - & - \\
\hline 4 & \pm & - & \pm & - & - & - & - & - \\
\hline \multicolumn{9}{|c|}{ Metal nanoparticles ( $\mathrm{ZnO}$ NPs) mM } \\
\hline 0.1 & +++ & +++ & +++ & +++ & ++ & ++ & ++ & + \\
\hline 0.5 & +++ & ++ & ++ & + & + & + & - & - \\
\hline 1 & ++ & ++ & + & - & - & - & - & - \\
\hline 2 & + & - & + & - & - & - & - & - \\
\hline 4 & \pm & - & \pm & - & - & - & - & - \\
\hline
\end{tabular}

+++ very good growth, ++ good growth, + growth, \pm not sure, - no growth

done by Al-Momani et al. (2007) indicated that the metal was accumulated on the cell wall, plasma membrane as well as in the cytoplasm. Li et al. (2011) studied the susceptibility of Gram-positive (Bacillus subtilis) and Gramnegative (Pseudomonas putida and E. coli) bacteria to $\mathrm{ZnO}$ NPs and found that Gram-negative organisms were more resistant to $\mathrm{ZnO}$ NPs. The cell wall of Gram-positive bacteria comprises of thicker peptidoglycan as compared to their Gram-negative counterparts which have an outer membrane. The outer membrane acts as impermeable lipid barrier and hence most of Gram-negative bacteria are resistant to most of the toxic substances like antibiotics, metals, etc.

Increased concentrations of zinc results in inhibition of the electron transport chain where as ZnO NPs results in the formation of reactive oxygen species (ROS) and lipid peroxidation resulting in apoptosis in human myeloblastic leukemia cells-HL60 (Premanathan et al. 2011). The toxicity of the $\mathrm{ZnO}$ NPs and their bulk counterparts on eukaryotes like zebrafish is found to be in the range of 0.04-0.099 mM (Xiong et al. 2011).

Effect of $\mathrm{Zn}$ and $\mathrm{ZnO}$ NPs on growth of halophilic archaea

Growth kinetics were studied in NGSM medium (Fig. 1; Table 2) and the concentration of $\mathrm{ZnCl}_{2} / \mathrm{ZnO} \mathrm{NPs}$ was selected based on the MIC results for the respective haloarchaeal strains.

Haloferax strain BBK2 in presence of $0.5 \mathrm{mM}$ of $\mathrm{ZnCl}_{2} /$ $\mathrm{ZnO}$ NPs reached its maximum OD of 1.31/1.4 in 7 days which was almost same when compared to the control, i.e., 1.36 in 6 days. The culture grew with doubling time of $37.9 \mathrm{~h}$ which increased with $\mathrm{ZnCl}_{2} / \mathrm{ZnO}$ NPs to $47.0 / 47.5$ (Fig. 1).

Halococcus strain BK6 in presence of $0.5 \mathrm{mM}$ of $\mathrm{ZnCl}_{2} /$ $\mathrm{ZnO}$ NPs reached its maximum optical density (OD at $600 \mathrm{~nm}$ ) of 1.22/0.69 in 7 days which was little lower when compared to control, i.e., 1.44 in 3 days (Fig. 1). The culture grew with doubling time of $16.1 \mathrm{~h}$ which increased with $\mathrm{ZnCl}_{2} / \mathrm{ZnO} \mathrm{NPs}$ to $53.6 / 72.2$.

Growth of Halorubrum strain BS17 was very slow with maximum OD of $0.87 / 0.92$ in 7 days in presence of $0.1 \mathrm{mM} \mathrm{ZnCl}_{2} / \mathrm{ZnO} \mathrm{NPs}$ which was comparable to the control, i.e., 0.84 in 7 days (Fig. 1). The culture grew with doubling time of $92.4 \mathrm{~h}$ which decreased with bulk $\mathrm{ZnCl}_{2}$ to $86.4 \mathrm{~h}$ and increased with $\mathrm{ZnO}$ NPs to $97.6 \mathrm{~h}$.

Haloarcula strain BS2 in presence of $0.1 \mathrm{mM}$ of $\mathrm{ZnCl}_{2} /$ $\mathrm{ZnO}$ NPs reached its maximum OD of 1.15/1.19 in 7 days which was almost same when compared to the control, i.e., 1.09 in 7 days. The culture grew with doubling time of $49.9 \mathrm{~h}$ which surprisingly decreased with $\mathrm{ZnCl}_{2} / \mathrm{ZnO} \mathrm{NPs}$ to $35.7 / 35.0$ (Fig. 1).

The four haloarchaeal genera Halococcus, Haloferax, Haloarcula and Halorubrum when grown in presence of $\mathrm{Zn}$ and $\mathrm{ZnO}$ NPs showed varying resistance in both complex (NTYE/NT) and minimal medium. The cultures exhibited increased resistance in complex media when compared with the minimal medium. This may be due to the complex formation by the media ingredients with the metal which decreases the availability of metal and/or metal NPs to the microorganisms. Similar observation was made by 

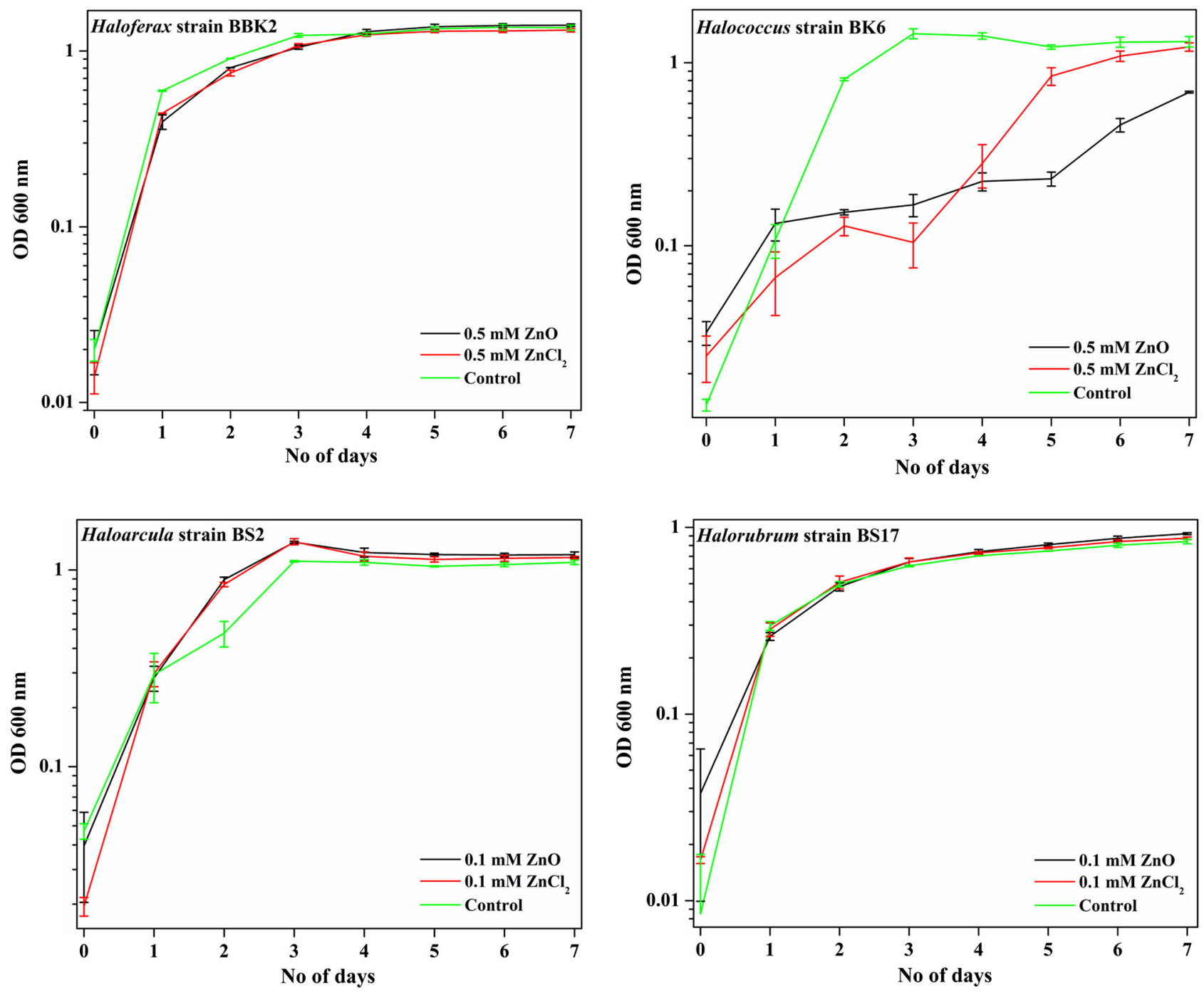

Fig. 1 Growth profile of the extremely halophilic archaeal cultures Haloferax strain BBK2, Halococcus strain BK6, Halorubrum strain BS17 and Haloarcula strain $\mathrm{BS} 2$ grown in NGSM with $\mathrm{ZnCl}_{2}$ and $\mathrm{ZnO} \mathrm{NPs}$

Table 2 Comparative study of the effect of $\mathrm{ZnCl}_{2}$ (heavy metal) and $\mathrm{ZnO}$ NPs (metal nanoparticle) on the growth profile of the haloarchaeal genera during growth in NGSM

\begin{tabular}{|c|c|c|c|c|c|c|c|c|c|}
\hline \multirow[t]{2}{*}{ Haloarchaeal isolates } & \multicolumn{3}{|c|}{ Control } & \multicolumn{3}{|c|}{$\mathrm{ZnCl}_{2}$} & \multicolumn{3}{|l|}{$\mathrm{ZnO}$} \\
\hline & $\lambda(\mathrm{h})$ & $\mu\left(\mathrm{h}^{-1}\right)$ & $t(\mathrm{~h})$ & $\lambda(\mathrm{h})$ & $\mu\left(\mathrm{h}^{-1}\right)$ & $t(\mathrm{~h})$ & $\lambda(\mathrm{h})$ & $\mu\left(\mathrm{h}^{-1}\right)$ & $t(\mathrm{~h})$ \\
\hline Halococcus strain BK6 $(1.0 \mathrm{mM})$ & 29.7 & 24.7 & 16.1 & 70.5 & 7.4 & 53.6 & 110.4 & 5.5 & 72.2 \\
\hline Haloferax strain BBK2 (0.5 mM) & - & 10.4 & 37.9 & - & 8.4 & 47.1 & - & 8.3 & 47.5 \\
\hline Haloarcula strain BS2 (0.1 mM) & - & 7.9 & 49.9 & - & 11.1 & 35.7 & - & 11.3 & 35.0 \\
\hline Halorubrum strain BS17 $(0.1 \mathrm{mM})$ & - & 4.3 & 92.4 & - & 4.5 & 86.4 & - & 4.0 & 97.6 \\
\hline
\end{tabular}

$\lambda$ lag phase time, $\mu$ growth rate, $t$ doubling time

Bragança and Furtado (2013) while studying the resistance of the haloarchaeon Halobacterium strain R1 to cadmium when grown in minimal medium. The overall doubling time of haloarchaea increased in presence of $\mathrm{ZnCl}_{2}$ and further increased in $\mathrm{ZnO}$ NPs. Interestingly, Haloarcula strain BS2 showed better growth in presence of bulk as well as Zn NPs. 
Pigment analysis

The haloarchaeal strains when grown in NGSM showed pink or mauve pigmentation (Fig. 2). The pigment was unaltered during growth in the presence of both bulk $\mathrm{Zn}$ or $\mathrm{ZnO}$ NPs. Extraction of the pigments in acetone showed characteristic peaks at 389, 471, 496 and $528 \mathrm{~nm}$ corresponding to bacterioruberins. Interestingly, a shift in the peaks $(323,394,477,503$ and 536) was observed when pigments were extracted in chloroform:methanol $(2: 1 \mathrm{v} / \mathrm{v})$.

Zn accumulation studies

The amount of $\mathrm{Zn}$ accumulated by whole cells of each genus varied when grown in $\mathrm{ZnCl}_{2}$ and $\mathrm{ZnO}$ NPs. The $\mathrm{ZnCl}_{2}$ accumulation analyzed by atomic absorption spectroscopy was seen as Haloferax strain BBK2 (287.2 $\left.\mathrm{mg} \mathrm{g}^{-1}\right)>$ Halococcus strain BK6 (165.9 $\left.\mathrm{mg} \mathrm{g}^{-1}\right)>$ Haloarcula strain BS2 (93.2 $\left.\mathrm{mg} \mathrm{g}^{-1}\right)>$ Halorubrum strain BS17 (29.9 $\mathrm{mg} \mathrm{g}^{-1}$ ), whereas for ZnO NPs accumulation was Haloferax strain BBK2 $\left(549.2 \mathrm{mg} \mathrm{g}^{-1}\right)>$ Halococcus strain BK6 (388.5 $\left.\mathrm{mg} \mathrm{g}^{-1}\right)>$ Haloarcula strain BS2 (28.5 $\left.\mathrm{mg} \mathrm{g}^{-1}\right)>$ Halorubrum strain BS17 (16.2 $\left.\mathrm{mg} \mathrm{g}^{-1}\right)$ (Table 3).

Among the four genera, Haloferax showed a higher $\mathrm{Zn}$ accumulation although both Halococcus and Haloferax were grown in $0.5 \mathrm{mM}$ of $\mathrm{ZnCl}_{2}$ and $0.5 \mathrm{mM}$ of $\mathrm{ZnO}$ NPs. Interestingly, the amount of $\mathrm{ZnO}$ NPs accumulated was more as compared to $\mathrm{ZnCl}_{2}$ as revealed by AAS. However, Haloarcula strain BS2 and Halorubrum strain BS17 grown in $0.1 \mathrm{mM}$ of $\mathrm{ZnCl}_{2}$ and $0.1 \mathrm{mM}$ of $\mathrm{ZnO}$ NPs showed higher accumulation of $\mathrm{ZnCl}_{2}$ than $\mathrm{ZnO}$ NPs. Our recent study by Das et al. (2014) indicated that Haloferax strain

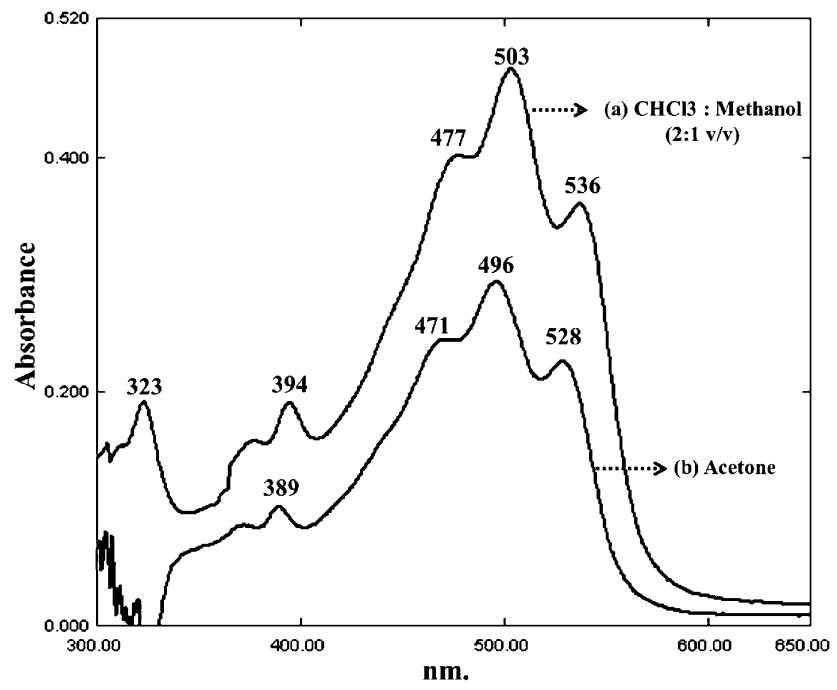

Fig. 2 Spectrophotometric scans of pigments from Halorubrum strain BS17 grown in NGSM containing $0.1 \mathrm{mM} \mathrm{ZnCl}_{2}$ and extracted using $a$ chloroform: methanol $(2: 1 \mathrm{v} / \mathrm{v})$ and $b$ acetone
Table 3 Bioaccumulation of $\mathrm{ZnCl}_{2}$ and $\mathrm{ZnO}$ NPs by the haloarchaeal strains

\begin{tabular}{lcc}
\hline Haloarchaeal strains & \multicolumn{2}{c}{ Bioaccumulation $\left(\mathrm{mg} \mathrm{g}^{-1}\right)$} \\
\cline { 2 - 3 } & $\mathrm{ZnCl}_{2}$ & $\mathrm{ZnO} \mathrm{NPs}$ \\
\hline Haloferax strain BBK2 & 287.2 & 549.6 \\
Haloarcula strain BS2 & 93.2 & 28.5 \\
Halorubrum strain BS17 & 29.9 & 16.2 \\
Halococcus strain BK6 & 165.9 & 388.5 \\
\hline
\end{tabular}

BBK2 was also resistant to cadmium $(\mathrm{Cd})$ and accumulated $21.08 \mathrm{and} /$ or $15.19 \%$ of $\mathrm{Cd}$ in the presence of $0.5 / 1 \mathrm{mM}$ Cd. Haloferax is known to produce exopolysaccharide (EPS) which protects the cells from direct contact with the metals and hence its resistance (Poli et al. 2011). Halococcal cells resist lysis when suspended in low-osmolarity solutions (3.5\% NaCl) (Mani et al. 2012; Legat et al. 2013). The cell wall of Halococcus is composed of heteropolysaccharide with acetylated amino sugars unlike glycoprotein S-layer in genus Haloferax (Schleifer et al. 1982; Kandler and Konig 1998). This could be a contributing factor for higher metal resistance of these organisms. On the other hand, Al-Mailem et al. (2011) studied the resistance and mercury $(\mathrm{Hg})$ volatilization $\left(\mathrm{Hg}^{2+}\right.$ to $\left.\mathrm{Hg}^{\circ}\right)$ and oil consumption capability of haloarchaea viz Haloferax, Halobacterium and Halococcus and found that genus Halococcus was the most efficient in $\mathrm{Hg}$ volatilization as compared with the other genera.

The haloarchaeal cells grown in NGSM medium with $\mathrm{ZnCl}_{2} / \mathrm{ZnO}$ NPs showed peaks for $\mathrm{Zn}$ on the cell surface when examined by SEM-EDX. However, the amount (percent) of $\mathrm{Zn}$ sorbed on the surface of cells of Haloferax strain BBK2 grown in the presence of $\mathrm{ZnCl}_{2}$ was greater $(21.77 \%)$ than cells grown in presence of $\mathrm{ZnO}$ NPs (14.89 \%) (Fig. 3). Peaks of $\mathrm{K}, \mathrm{Mg}, \mathrm{Ca}$, which are components of the growth medium, were also detected in SEMEDX analysis. Recent study by Williams et al. (2013) investigated the ability of halophilic archaeon Halobacterium saccharovorum to tolerate up to $0.01 \mathrm{mM} \mathrm{Zn} \mathrm{with} \mathrm{max-}$ imum of $68.6 \%$ biosorption, while at higher $\mathrm{Zn}$ concentration $(0.1 \mathrm{mM})$ only $19.5 \%$ of $\mathrm{Zn}$ was biosorbed.

Figure 4 depicts the XRD pattern of dialysed cells of Haloferax strain BBK2 grown in presence of $\mathrm{ZnCl}_{2}$ and/ $\mathrm{ZnO}$ NPs. The XRD analysis of the cells showed peaks between $22^{\circ}$ and $57^{\circ}$ for cells grown in presence of $\mathrm{ZnCl}_{2}$. This indicated the difference in crystallinity due to the sorption of bulk $\mathrm{ZnCl}_{2}$ by the haloarchaeal cell components. At $2 \theta$ of $28.8^{\circ}$, weak reflection was seen which could be attributed to the reflection of $\mathrm{ZnS}$ sphalerite phase (111) as reported by Dedova et al. 2007 for $\mathrm{ZnCl}_{2}$ sample. The broadening of the peaks indicated the amorphous nature of the sample. However, XRD profile of BBK2 cells grown in 

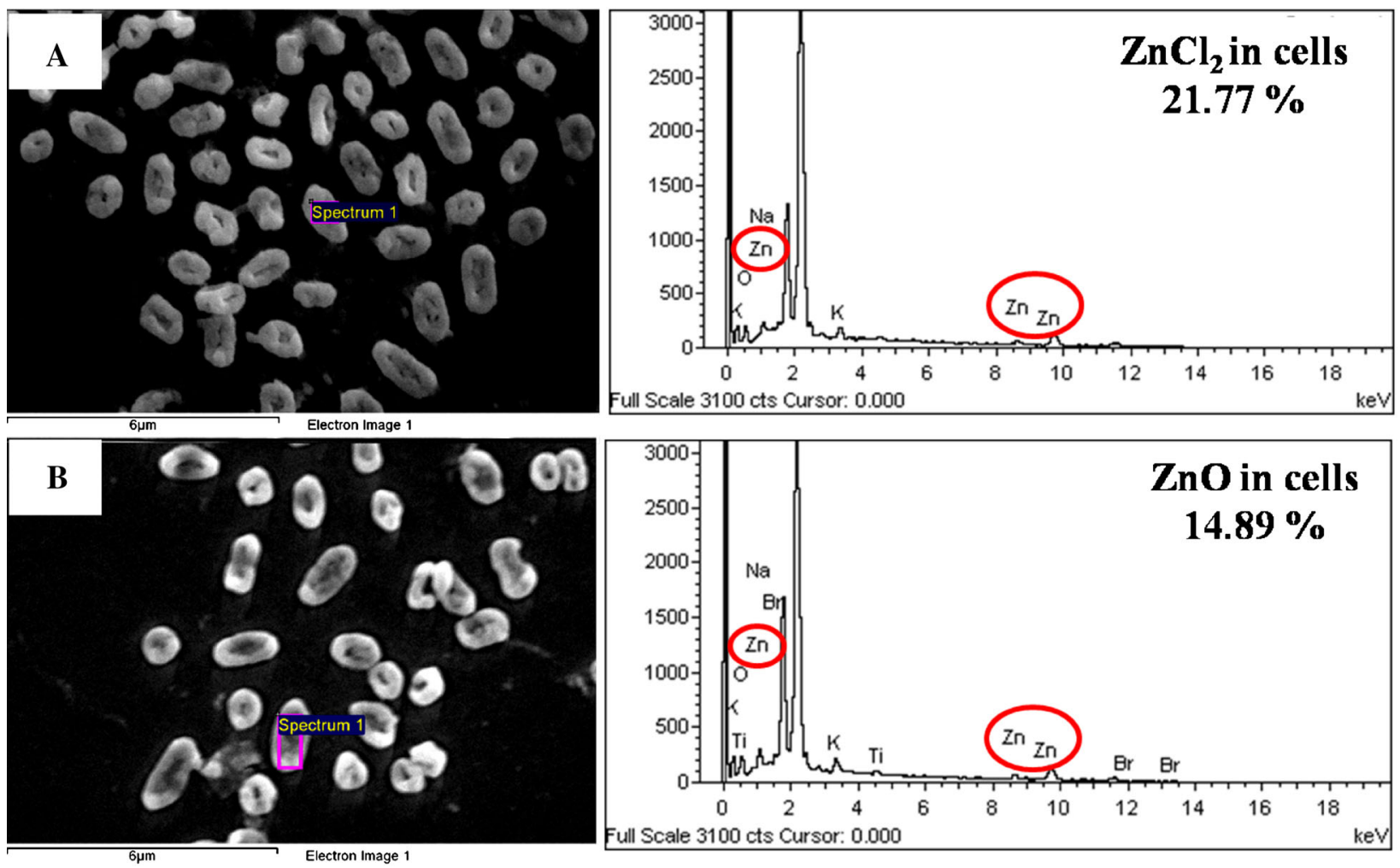

Fig. 3 Scanning electron microscopy (SEM) and energy dispersive X-ray (EDX) analysis of haloarchaeon Haloferax strain BBK2, grown in NGSM containing $0.1 \mathrm{mM}$ a $\mathrm{ZnCl}_{2}$ and $\mathbf{b} \mathrm{ZnO}$ nanoparticles

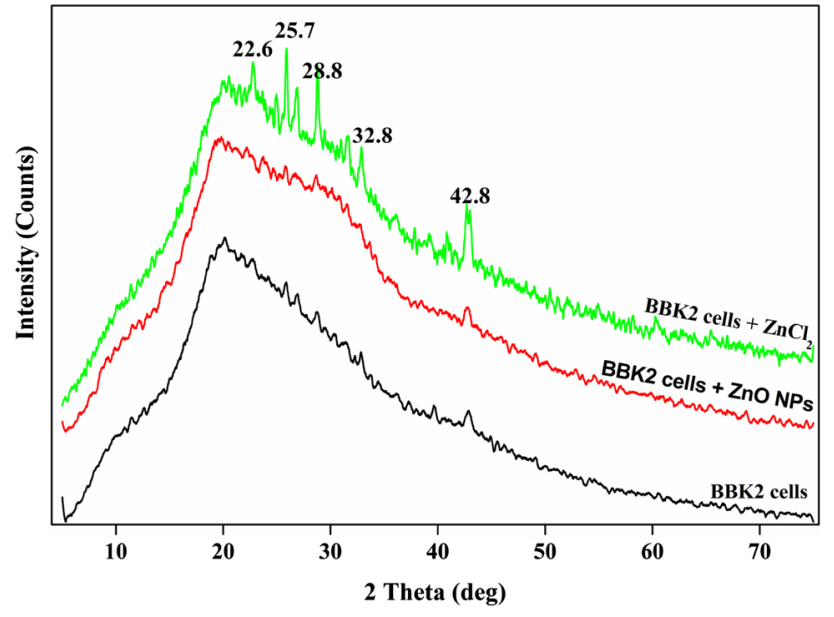

Fig. 4 X-ray diffraction pattern of haloarchaeon Haloferax strain BBK2 cells grown in presence of $\mathrm{ZnCl}_{2}$ and $\mathrm{ZnO} \mathrm{NPs}$

presence of $\mathrm{ZnO}$ NPs and without $\mathrm{Zn}$ showed no significant difference.

\section{Conclusions}

In conclusion, the four representative genera Halococcus, Haloferax, Halorubrum and Haloarcula used in the study were able to tolerate and grow in complex as well as minimal media in presence of $\mathrm{Zn}$ and $\mathrm{ZnO}$ NPs. Halococcus strain BK6 and Haloferax strain BBK2 showed the best resistance of up to 2.0 and $1.0 \mathrm{mM}$ in both complex and minimal media.

Acknowledgments JB thanks Birla Institute of Technology and Science, Pilani for the BITS Seed Grant 2013. BBS thanks Council of Scientific and Industrial Research (CSIR), India, for Senior Research Fellowship (SRF) (09/919(0016)/2012-EMR-I). DD received the BITS Fellowship 2013. The authors are grateful to Mr. Areef Sardar, National Institute of Oceanography (NIO) for the SEM-EDX analysis. Authors thank Prof. G. N. Nayak and Ms. Samida Volvoikar, Department of Marine Science, Goa University for AAS analysis.

Open Access This article is distributed under the terms of the Creative Commons Attribution License which permits any use, distribution, and reproduction in any medium, provided the original author(s) and the source are credited.

\section{References}

Acosta JA, Jansen B, Kalbitz K, Faz A, Martínez-Martínez S (2011) Salinity increases mobility of heavy metals in soils. Chemosphere 85:1318-1324

Al-Mailem DM, Al-Awadh H, Sorkhoh NA, Eliyas M, Radwan SS (2011) Mercury resistance and volatilization by oil utilizing 
haloarchaea under hypersaline conditions. Extremophiles 15:39-44

Al-Momani FA, Massadeh AM, Hadady YA (2007) Uptake of zinc and copper by halophilic bacteria isolated from the Dead sea shore, Jordan. Biol Trace Elem Res 115:291-300

Andreini C, Banci L, Bertini I, Rosato A (2006) Zinc through the three domains of life. J Proteome Res 5:3173-3178

Baranyi J, Roberts TA (1994) A dynamic approach to predicting bacterial growth in food. Int J Food Microbiol 23:277-294

Bini E (2010) Archaeal transformation of metals in the environment. FEMS Microbiol Ecol 73:1-16

Bragança JM, Furtado I (2009) Haloarchaea associated with salt crystals obtained from solar salterns of Goa, India. In: Visual Image, Microbe Library org, American Society for Microbiology

Bragança JM, Furtado I (2013) Resistance of Halobacterium strain $\mathrm{R} 1$ to cadmium during growth in mineral salts medium devoid of growth factors. Asian J Microbiol Biotech Env Sci 15:299-302

Choudhury R, Srivastava S (2001) Zinc resistance mechanisms in bacteria. Curr Sci 81:768-775

Das D, Salgaonkar BB, Mani K, Bragança JM (2014) Cadmium resistance in extremely halophilic archaeon Haloferax strain BBK2. Chemosphere 112:385-392

Dedova T, Volobujeva O, Klauson J, Mere A, Krunks M (2007) ZnO nanorods via spray deposition of solutions containing zinc chloride and thiocarbamide. Nanoscale Res Lett 2:391-396

Gadd GM (2009) Biosorption: critical review of scientific rationale, environmental importance and significance for pollution treatment. J Chem Technol Biotechnol 84:13-28

Gelabert A, Pokrovsky OS, Viers J, Schott J, Boudou A, FeurtetMazel A (2006) Interaction between zinc and freshwater and marine diatom species: Surface complexation and $\mathrm{Zn}$ isotope fractionation. Geochim Cosmochim Acta 70:839-857

Green-Ruiz C, Rodriguez-Tirado V, Gomez-Gil B (2008) Cadmium and zinc removal from aqueous solutions by Bacillus jeotgali: $\mathrm{pH}$, salinity and temperature effects. Bioresour Technol 99:3864-3870

Guine V, Spadini L, Sarret G, Muris M, Delolme C, Gaudet JP, Martins JMF (2006) Zinc Sorption to Three Gram-Negative Bacteria: Combined Titration, Modeling, and EXAFS Study. Environ Sci Technol 40:1806-1813

Gunalan S, Sivaraj R, Rajendran V (2012) Green synthesized ZnO nanoparticles against bacterial and fungal pathogens. Prog Nat Sci Mater Int 22:693-700

Kandler O, Konig H (1998) Cell wall polymers in archaea (archaebacteria). Cell Mol Life Sci 54:305-308

Kaur A, Pan M, Meislin M, Facciotti MT, El-Gewely R, Baliga NS (2006) A systems view of haloarchaeal strategies to withstand stress from transition metals. Genome Res 16:841-854

Kottemann M, Kish A, Iloanusi C, Bjork S, Diruggiero J (2005) Physiological responses of the halophilic archaeon Halobacterium sp. strain NRC1 to desiccation and gamma irradiation. Extremophiles 9:219-227

Legat A, Denner EBM, Dornmayr-Pfaffenhuemer M, Pfeiffer P, Knopf B, Claus H, Gruber C, König H, Wanner G, Stan-Lotter H (2013) Properties of Halococcus salifodinae, an isolate from Permian rock salt deposits, compared with Halococci from surface waters. Life 3:244-259

Li M, Pokhrel S, Jin X, Madler L, Damoiseaux R, Hoek EMV (2011) Stability, bioavailability, and bacterial Toxicity of $\mathrm{ZnO}$ and IronDoped $\mathrm{ZnO}$ nanoparticles in aquatic Media. Environ Sci Technol 45:755-761

Lipovsky A, Nitzan Y, Gedanken A, Lubart R (2011) Antifungal activity of $\mathrm{ZnO}$ nanoparticles - the role of ROS mediated cell injury. Nanotechnology 22:105101
Ma Y, Galinski EA, Grant WD, Oren A, Ventosa A (2010) Halophiles 2010: life in saline environments. Appl Environ Microbiol 76:6971-6981

Mangold S, Potrykus J, Björn E, Lövgren L, Dopson M (2013) Extreme zinc tolerance in acidophilic microorganisms from the bacterial and archaeal domains. Extremophiles 17:75-85

Mani K, Salgaonkar BB, Bragança JM (2012) Culturable halophilic archaea at the initial and final stages of salt production in a natural solar saltern of Goa, India. Aquat Biosyst 8:15

Monteiro CM, Castro PML, Malcata FX (2011) Biosorption of zinc ions from aqueous solution by the microalga Scenedesmus obliquus. Environ Chem Lett 9:169-176

Nieto JJ, Ventosa A, Ruiz-Berraquero F (1987) Susceptibility of Halobacteria to heavy metals. Appl Environ Microbiol 53:1199-1202

Paula DP, Gleny A, Martha H, Patricia P, Susana S, Fabrizio Q, Gonzalo R, Pedro S, Diana A, Karem G, Carlos CO (2013) Kinetics of arsenite removal by halobacteria from a highly and Andean Chilean Salar. Aquat Biosyst 9:8

Poli A, Di Donato P, Abbamondi GR, Nicolaus B (2011) Synthesis, production and biotechnological applications of exopolysaccharides and polyhydroxyalkanoates by archaea. Archaea 2011:693253. doi:10.1155/2011/693253

Popescu G, Dumitru L (2009) Biosorption of some heavy metals from media with high salt concentrations by halophilic Archaea. Biotechnol Biotechnol EQ:791-795 (23/2009/SE)

Premanathan M, Karthikeyan K, Jeyasubramanian K, Manivannan G (2011) Selective toxicity of $\mathrm{ZnO}$ nanoparticles toward Grampositive bacteria and cancer cells by apoptosis through lipid peroxidation. Nanomed Nanotech Biol Med 7:184-192

Salgaonkar BB, Kabilan M, Nair A, Sowmya G, Bragança JM (2012) Interspecific interactions among members of family Halobacteriaceae from natural solar salterns. Probiotics Antimicrob Proteins 4:98-107

Schleifer KH, Steber J, Mayer H (1982) Chemical composition and structure of the cell wall of Halococcus morrhuae. Zbl Bakt Hyg 1 Abt Orig 3:171-178

Schubert BA, Lowenstein TK, Timofeeff MN, Matthew A, Parker MA (2010) Halophilic Archaea cultured from ancient halite, Death Valley, California. Environ Microbiol 12:440-454

Sinha R, Karan R, Sinha A, Khare SK (2011) Interaction and nanotoxic effect of $\mathrm{ZnO}$ and $\mathrm{Ag}$ nanoparticles on mesophilic and halophilic bacterial cells. Bioresour Technol 102:1516-1520

Williams GP, Gnanadesigan M, Ravikumar S (2013) Biosorption and bio-kinetic properties of solar saltern Halobacterial strains for managing $\mathrm{Zn}^{2+}, \mathrm{As}^{2+}$ and $\mathrm{Cd}^{2+}$ metals. Geomicrobiol $\mathrm{J}$ 30:497-500

Xiong D, Fang T, Yu L, Sima X, Zhu W (2011) Effects of nano-scale $\mathrm{TiO}_{2}, \mathrm{ZnO}$ and their bulk counterparts on zebra fish: acute toxicity, oxidative stress and oxidative damage. Sci Total Environ 409:1444-1452

You J, Zhang Y, Hu Z (2011) Bacteria and bacteriophage inactivation by silver and zinc oxide nanoparticles. Colloids Surf B Biointerfaces 85:161-167

Zeng J, Wang WX (2009) The importance of cellular phosphorus in controlling the uptake and toxicity of cadmium and zinc in Microcystis aeruginosa, a freshwater cyanobacterium. Environ Toxicol Chem 28:1618-1626

Zhao L, Yang F, Yan X, Huo Z, Zhang G (2012) Heavy metal concentrations in surface sediments and Manila Clams (Ruditapes philippinarum) from the Dalian Coast, China after the Dalian Port Oil Spill. Biol Trace Elem Res 149:241-247

Zhao S, Feng C, Wang D, Liu Y, Shen Z (2013) Salinity increases the mobility of $\mathrm{Cd}, \mathrm{Cu}, \mathrm{Mn}$, and $\mathrm{Pb}$ in the sediments of Yangtze Estuary: relative role of sediments' properties and metal speciation. Chemosphere 91:977-984 